\title{
OPEN Antimicrobial responses of peripheral and central nervous system glia against Staphylococcus aureus
}

\author{
Indra N. Choudhury, 1,2,5, Anu Chacko ${ }^{1,2,5}$, Ali Delbaz ${ }^{1,2}$, Mo Chen ${ }^{1,2}$, Souptik Basu ${ }^{1,2}$, \\ James A. St John ${ }^{1,2,3}$, Flavia Huygens ${ }^{4}$ \& Jenny A. K. Ekberg ${ }^{1,2,3}$
}

Staphylococcus aureus infections of the central nervous system are serious and can be fatal. S. aureus is commonly present in the nasal cavity, and after injury to the nasal epithelium it can rapidly invade the brain via the olfactory nerve. The trigeminal nerve constitutes another potential route of brain infection. The glia of these nerves, olfactory ensheathing cells (OECs) and trigeminal nerve Schwann cells (TgSCs), as well as astrocytes populating the glia limitans layer, can phagocytose bacteria. Whilst some glial responses to $S$. aureus have been studied, the specific responses of different glial types are unknown. Here, we compared how primary mouse OECs, TgSCs, astrocytes and microglia responded to S. aureus. All glial types internalized the bacteria within phagolysosomes, and S. aureus-conjugated BioParticles could be tracked with subtle but significant differences in time-course of phagocytosis between glial types. Live bacteria could be isolated from all glia after $24 \mathrm{~h}$ in culture, and microglia, OECs and TgSCs exhibited better protection against intracellular $S$. aureus survival than astrocytes. All glial types responded to the bacteria by cytokine secretion. Overall, OECs secreted the lowest level of cytokines, suggesting that these cells, despite showing strong capacity for phagocytosis, have immunomodulatory functions that can be relevant for neural repair.

Bacterial invasion of the central nervous system (CNS) is relatively rare but can result in significant mortality and morbidity. Pathogen invasion of the CNS can occur via the blood brain barrier (BBB) or blood-cerebrospinal fluid barrier (BCSFB). An alternative route is via the nerves that connect the nasal cavity and the CNS, the olfactory nerve (cranial nerve I) and the intranasal branches of the trigeminal nerve (cranial nerve $\mathrm{V}$ ), which terminate in the olfactory bulb and brainstem, respectively ${ }^{1,2}$. In the olfactory system, the cell bodies of primary olfactory neurons are localised in the olfactory neuroepithelium at the roof of the nasal cavity. Their dendrites extend directly into the nasal cavity, where odorant detection takes place, whilst their axons project all the way into the olfactory bulb in the brain, where they synapse onto second order neurons. Thus, the primary olfactory nervous system is a one-synapse route from the olfactory neuroepithelium directly to the CNS ${ }^{3}$. The olfactory nerve is unique in that it regenerates throughout life ${ }^{3,4}$; perhaps this nerve has evolved to regenerate continuously because its dendrites are exposed to microbes and toxins in the nasal cavity ${ }^{5}$. Whilst cell bodies of trigeminal neurons are localised in trigeminal ganglia far from the periphery, the distal ends of some trigeminal axons that innervate the nasal cavity are close to the apical surface of the nasal epithelium ${ }^{6}$. Despite the anatomy of the olfactory and trigeminal nerves, they appear to be only rarely affected by fulminating microorganism infection.

The intact nasal epithelium usually provides a barrier preventing invasion against most pathogens, and the epithelium contains strong innate and adaptive immune system components, accompanied by those in the nearby nasal-associated lymphoid tissue $\mathrm{e}^{7,8}$. The nerves are also protected by their respective glia, which have strong innate immune properties. The glia of the primary olfactory nervous system, olfactory ensheathing cells (OECs), which ensheathe bundles of olfactory axons, exhibit capacity for phagocytosis of cell debris resulting from olfactory neuron turnover ${ }^{9-11}$. Both OECs ${ }^{12-16}$ and the glia of the trigeminal nerve, trigeminal Schwann cells (TgSCs) ${ }^{16}$, can respond to and phagocytose bacteria. OECs and Schwann cells have, however, been shown

${ }^{1}$ Clem Jones Centre for Neurobiology and Stem Cell Research, Griffith University, Nathan, QLD, Australia. ${ }^{2}$ Menzies Health Institute Queensland, Griffith University, Southport, QLD 4222, Australia. ${ }^{3}$ Griffith Institute for Drug Discovery, Griffith University, Nathan, QLD, Australia. ${ }^{4}$ Centre for Immunology and Infection Control, School of Biomedical Sciences, Faculty of Health, Queensland University of Technology, Brisbane, QLD, Australia. ${ }^{5}$ These authors contributed equally: Indra N. Choudhury and Anu Chacko ${ }^{\circledR}$ email: j.ekberg@griffith.edu.au 
to respond differently to pathogens and pathogen-associated molecular patterns (PAMPs) ${ }^{14}$. Should microbes invade the olfactory or trigeminal nerves, they also encounter a "third layer of defence" when they reach the glia limitans layer, the demarcation between the PNS and CNS, where astrocytes are present ${ }^{17}$. After encountering bacterial antigens, astrocytes both rapidly participate in acute innate immune responses and prompt an adaptive immune response ${ }^{18,19}$. Microglia are the innate immune cells and resident phagocytes of the brain ${ }^{20}$ and they defend the brain from invading bacteria ${ }^{21}$.

A small number of bacteria are thought able to evade these protection mechanisms and invade the CNS via the olfactory and/or trigeminal nerves, such as Neisseria meningitidis, Streptococcus pneumoniae, Chlamydia pneumoniae, Listeria monocytogenes, Streptococcus pneumoniae, Nocardia cyriacigeorgica and Burkholderia pseudomallei, as well as some viruses, such as herpes simplex type 1 (HSV1) 2,22 and potentially SARS-CoV- $2^{23}$. Injury to the nasal epithelium may increase pathogen invasion of the underlying nerves, as has been shown for B. pseudomallei ${ }^{24}$, and may also allow invasion by microbes present in the nasal cavity, but not normally gaining access to nerves.

One bacterium known to be capable of CNS infection that is commonly present in the nasal cavity is Staphylococcus aureus; $\sim 50 \%$ of healthy adults harbour S. aureus in the nasal cavity either persistently or intermittently ${ }^{25}$. S. aureus causes $1-9 \%$ of bacterial meningitis cases in adults ${ }^{26,27}$ and is one of the most common causes of brain abscess $^{28,29}$. S. aureus can infect human microvascular endothelial cells and thus has capacity for crossing the blood-brain barrier $(\mathrm{BBB})^{30}$, but is also thought to use other infection routes ${ }^{2}$. After experimental injury to the nasal epithelium, $S$. aureus can rapidly invade the olfactory bulb via the olfactory nerve $\mathrm{e}^{12,13}$; thus, this bacterium, once it reaches the olfactory (and potentially the trigeminal nerve) is able to withstand the immune response mounted by peripheral nerve glia.

Some key responses of OECs to $S$. aureus have been studied. Following challenge with $S$. aureus, expression of inducible nitric oxide synthase (iNOS) mRNA was shown to be strongly upregulated in OECs, resulting in nitric oxide (NO) production (measured as nitrite concentration), accompanied by nuclear translocation of nuclear factor kappa B (NFkB). OECs were also shown to express increased amounts of mRNA for key innate immune components, such as lysozyme, interleukin 6 (IL-6) and the chemokine C-X-C motif ligand 1 (CXCL1 ; also known as Grol or KC) in response to $S$. aureus ${ }^{12,13}$. However, key aspects of OEC responses to $S$. aureus remain to be characterised, such as the time-course of internalization as well as a broad analysis of cytokine and chemokine production. Furthermore, OECs have been shown to mount a much more powerful immune response to Escherichia coli and PAMPs than Schwann cells ${ }^{14}$, suggesting differences between types of glia in their handling of pathogens. To date, the responses by different glial types to $S$. aureus have not been compared. Determining how glia in the olfactory and trigeminal nerves, and in the glia limitans layer, respond to different bacteria is the key to understanding how certain pathogens can invade the CNS via peripheral nerves. In the current study, we compared how OECs, TgSCs, astrocytes and microglia responded to S. aureus infection, in particular the timecourse of internalization and production of a range of cytokines and chemokines.

\section{Results}

Intracellular survival of $\boldsymbol{S}$. aureus differs between glial types. To investigate the susceptibility of different glial cell types to $S$. aureus infection, we compared the adhesion and invasion capacity of live $S$. aureus between primary OECs and TgSCs (PNS glia from the olfactory and trigeminal nerve, respectively) with astrocytes and microglia (CNS glia). We first exposed the cells to $S$. aureus for $1 \mathrm{~h}$, and then applied antibiotics to the medium to inhibit extracellular survival of the bacteria after which cells/bacteria were incubated for a further 6 $\mathrm{h}$ and $24 \mathrm{~h}$. At $1 \mathrm{~h}$ after commencement of the assay, OECs and TgSCs that were not inoculated with S. aureus exhibited typical bipolar morphology, while astrocytes had multi-branched broad morphology and microglia showed a resting or ramified morphology (Fig. 1A-D). When the cells were inoculated with $S$. aureus, bacteria were present along the length of the processes of the OECs and TgSCs (Fig. 1E-F). While there appeared to be minor changes to the cell morphology, with some cells becoming broader while other became more elongated. Measurements of cell length revealed that the presence of $S$. aureus did not alter overall cell length of OECs, TgSCs and microglia at $1 \mathrm{~h}$ and $6 \mathrm{~h}$ (Fig. 2D). At $24 \mathrm{~h}$, however, TgSCs exposed to S. aureus were significantly longer than control cells (Fig. 2D). In contrast, astrocytes underwent considerable morphological changes when exposed to the bacteria; their overall lengths were significantly greater at all timepoints (Figs. 1G, 2D). Microglia showed uptake of bacteria localised in the perinuclear area at $1 \mathrm{~h}($ Fig. $1 \mathrm{H})$. At $24 \mathrm{~h}$ though a significant decrease in size of infected microglia was observed (Fig. 2D). After the antibiotic protection media was added to prevent extracellular survival of the bacteria, the bacteria were clearly internalised within the cells at $6 \mathrm{~h}$ post exposure for all glial cells. Some bacteria were present in the processes of the cells (arrows, Fig. 1I-K), but majority of bacteria appeared to be localised in the perinuclear region (arrows with tails). At $24 \mathrm{~h}$, the bacteria were mainly in the perinuclear region of OECs, TgSCs and microglia (Fig. 1M-N) with few bacteria localised in the processes of OECs, TgSCs and microglia (Fig. 1M-N,P). In contrast, while bacteria were in the perinuclear region of astrocytes, there appeared to be more bacteria present along the branches (arrows, Fig. 1O).

To quantify the amount of bacteria that adhered or were internalised into cells, cells were washed and then lysed at different times and lysates were plated onto selective BHI agar plates. We observed significant differences between types of glia regarding $S$. aureus adherence to the cells. Significantly more bacteria adhered to astrocytes than to TgSCs and microglia after $1 \mathrm{~h}$ (Fig. 2A). OECs showed significantly higher bacterial adherence than microglia too (Fig. 2A). Following antibiotic treatment at $1 \mathrm{~h}$ to prevent extracellular survival of bacteria, and subsequent analysis at $6 \mathrm{~h}$ post exposure to $S$. aureus, live bacteria could be isolated from all three glial types. There was, however, no difference in the amount of bacteria between the glial types (Fig. 2B). In contrast, at $24 \mathrm{~h}$ post exposure, there were significantly more bacteria in astrocytes as compared to OECs, TgSCs and microglia, suggesting a decrease in intracellular survival or a more efficient bacterial killing by OECs, TgSCs and microglia 


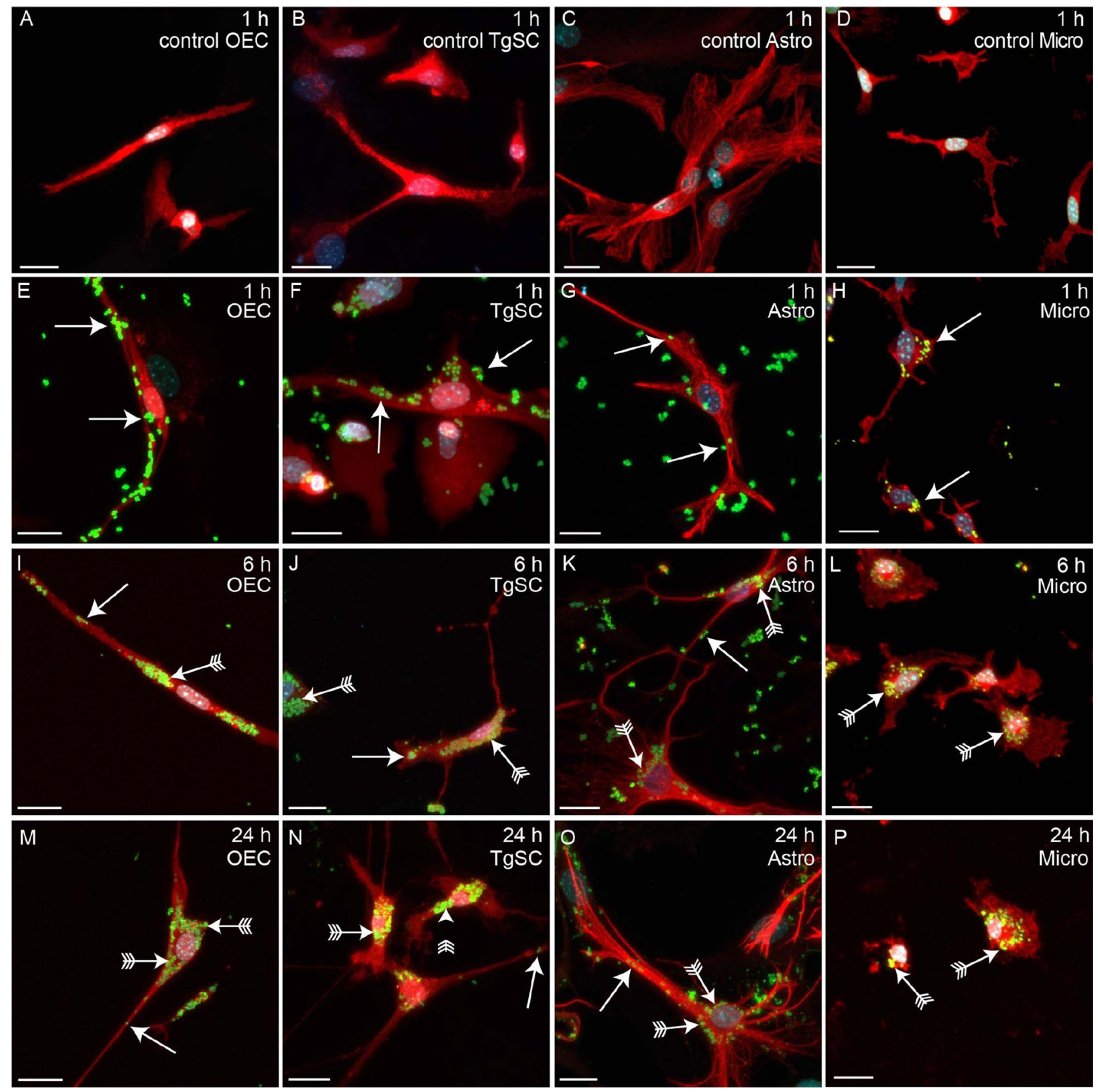

Figure 1. S. aureus attaching to and being internalised into OECs, TgSCs, astrocytes and microglia. Panels show primary cultures of OECs (left panels), TgSCs (second panels), astrocytes (third panels) and microglia (right panels) from S100 $\beta$-DsRed mice, in which all glia express the DsRed protein. For OECs and TgSCs, red labelling shows DsRed; for astrocytes, red labelling shows GFAP (these cells express low levels of DsRed); for microglia, red labelling shows Iba-1 (these cells express low level of DsRed) and Hoechst for nucleus staining. (A-D) Control wells of the four glial types $1 \mathrm{~h}$ post addition of medium without bacteria and antibiotics. (E-H) At $1 \mathrm{~h}$ post exposure to $S$. aureus, bacteria had adhered to the cell surface (arrow) and internalized (arrow) within the microglia. (I-P) After $1 \mathrm{~h}$, antibiotics were added, preventing survival of bacteria in the medium. (I-L) S. aureus in glia at $6 \mathrm{~h}$ post exposure, some bacteria were present in the processes (arrows) while larger amounts accumulated in the perinuclear region (arrows with tail). (M-P) At $24 \mathrm{~h}$ post exposure, most bacteria were present in the perinuclear region (arrows with tail) while some bacteria were also present in the processes (arrows). Scale bar: $20 \mu \mathrm{m}$.

as compared to astrocytes (Fig. 2C). We analysed the invasion frequency (the percentage of the initially adhered bacteria that were inside cells at $6 \mathrm{~h}$ ); there was no significant difference in invasion frequency between cell types (Fig. 2E). We also determined the percentage of bacteria that survived intracellularly (amount of bacteria isolated from inside cells at $24 \mathrm{~h}$ compared to $6 \mathrm{~h}$ ) and found no significant difference (Fig. 2F). To account for changes in cell numbers during the assay (proliferation or death), a cell count was performed and intracellular survival was calculated on the cell numbers at $24 \mathrm{~h}$ (OECs, TgSCs and astrocytes showed no significant change in cell 

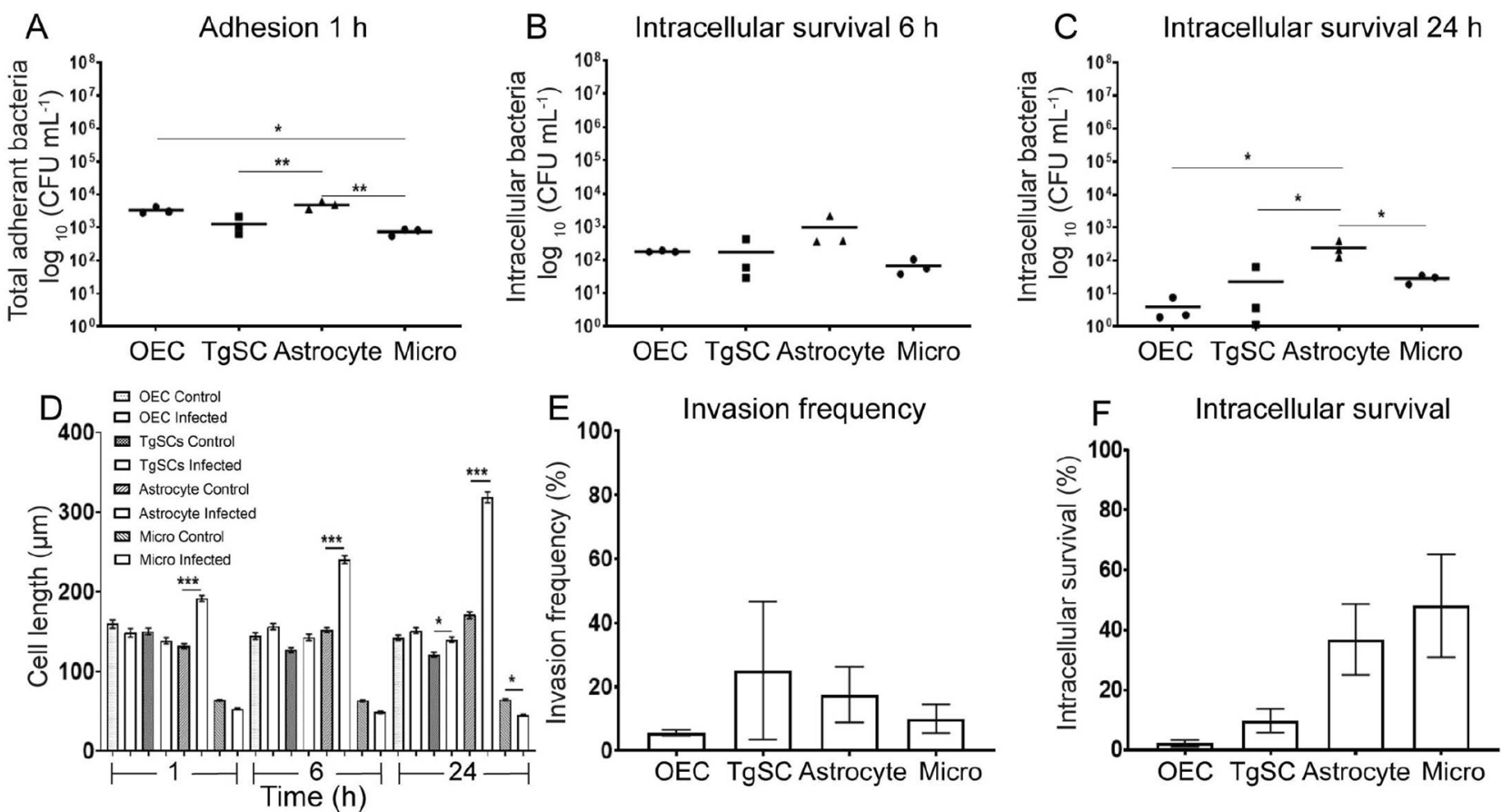

Figure 2. S. aureus adhesion to, and invasion of, primary glia. (A) Adhesion assays. Cell monolayers were incubated with $S$. aureus (MOI 100:1) for $1 \mathrm{~h}$, followed by washing and colony counting to determine the number of bacteria (CFU) that adhered to cells. (B,C) Intracellular survival assay. After $1 \mathrm{~h}$ of exposure to $S$. aureus, a combination of three antibiotics was added to the medium to remove extracellular bacteria. After 6 $\mathrm{h}($ B) or $24 \mathrm{~h}(\mathrm{C})$, cells were lysed to recover intracellular bacteria, and colony counts were performed. Results (A-C) were normalized with the number of viable glia cells. (D) Cell morphology (length) measurement. Manual measurement of cell length (10-15 cells/Field of view (FOV) with 10-15 FOV, a total of 200 cells were counted manually) using NIS software at different time-points after exposure to $S$. aureus with control wells. (E) Invasion frequency. The percentages of initially adhered bacteria that later invaded the cells was determined (CFUs isolated from cells at $6 \mathrm{~h} \mathrm{[B]} \mathrm{divided} \mathrm{by} \mathrm{CFUs} \mathrm{adhering} \mathrm{to} \mathrm{cells} \mathrm{at} 1 \mathrm{~h}[\mathrm{~A}]$ ). (F) Intracellular survival. The percentage of bacteria inside cells was compared between the $24 \mathrm{~h}$ and $6 \mathrm{~h}$ time-point (CFUs isolated from cells at $24 \mathrm{~h}$ divided by CFUs isolated from cells at $6 \mathrm{~h}$ ). Results for (E,F) were normalized with the number of viable glia cells. For (A-D) data shows mean \pm SEM (two way ANOVA with Tukey's multiple comparison test), (E-F) bars show mean \pm SEM, (Kruskal-Wallis test with Dunn's multiple comparison), $\mathrm{n}=3$ biological and 3 technical replicates ( 3 wells with 4000 cells per well), ${ }^{\star} p \leq 0.05,{ }^{* *} p \leq 0.01,{ }^{\star * *} p \leq 0.001$.

numbers; only microglia showed a significant decrease in cell number over the assay). Thus the effect observed in the results is due to glial responses to bacteria and not due to cell death occurring post infection.

Phagocytosis of S. aureus and pHrodo S. aureus BioParticles by glial cell types. To determine whether the glia phagocytosed $S$. aureus and internalised the bacteria in lysosomes, we stained the cells with a lysosomal membrane protein 2 marker (LAMP-2) which is a protein component of the lysosome membrane. The lysosomes function to fuse to foreign particles to form a phagolysosome which then aids in their acidification and degradation. We observed that all glial cells showed positive LAMP-2 staining around the bacterial stains of S. aureus (Fig. 3) demonstrating that the bacteria was internalized or colocalized inside lysosomes.

To determine the time course of glial phagocytosis of $S$. aureus (resulting in the bacteria being internalized into lysosomes) we exposed the glia to $\mathrm{pH}$-sensitive (pHrodo) S. aureus BioParticles, which exhibit fluorescence only when in an acidic environment (i.e. in phagolysosomes). The phagocytosis assay was performed using the four types of glia for increasing durations ranging from $30 \mathrm{~min}$ to $8 \mathrm{~h}$, with imaging of the cells every $30 \mathrm{~min}$ (Fig. 4). The cells internalized an increasing amount of BioParticles over time (Fig. 4M). In microglia, a significantly higher proportion of cells internalized the BioParticles at $30 \mathrm{~min}$, compared to astrocytes, TgSCs or OECs. Significantly more astrocytes and TgSCs internalised the BioParticles than OECs. BioParticle internalization into acidic cellular compartment differed between astrocytes and OECs after $3.5 \mathrm{~h}$ (Fig. 4M). At $4.5 \mathrm{~h}$ post exposure, TgSCs contained more phagocytosed particles than OECs (Fig. 4M) .

Glia produce multiple cytokines and chemokines after exposure to S. aureus. To gain insight into the innate immune responses to $S$. aureus by the different glia, we measured the production of cytokines and chemokines at different time-points post exposure to bacteria (1, 6 and $24 \mathrm{~h}$ post exposure). The results showed significant production of several cytokines (Fig. 5) and chemokines (Fig. 6) as early as $1 \mathrm{~h}$ post exposure to $S$. aureus by all four glia types. The response included increased secretion of pro-inflammatory cytokines 


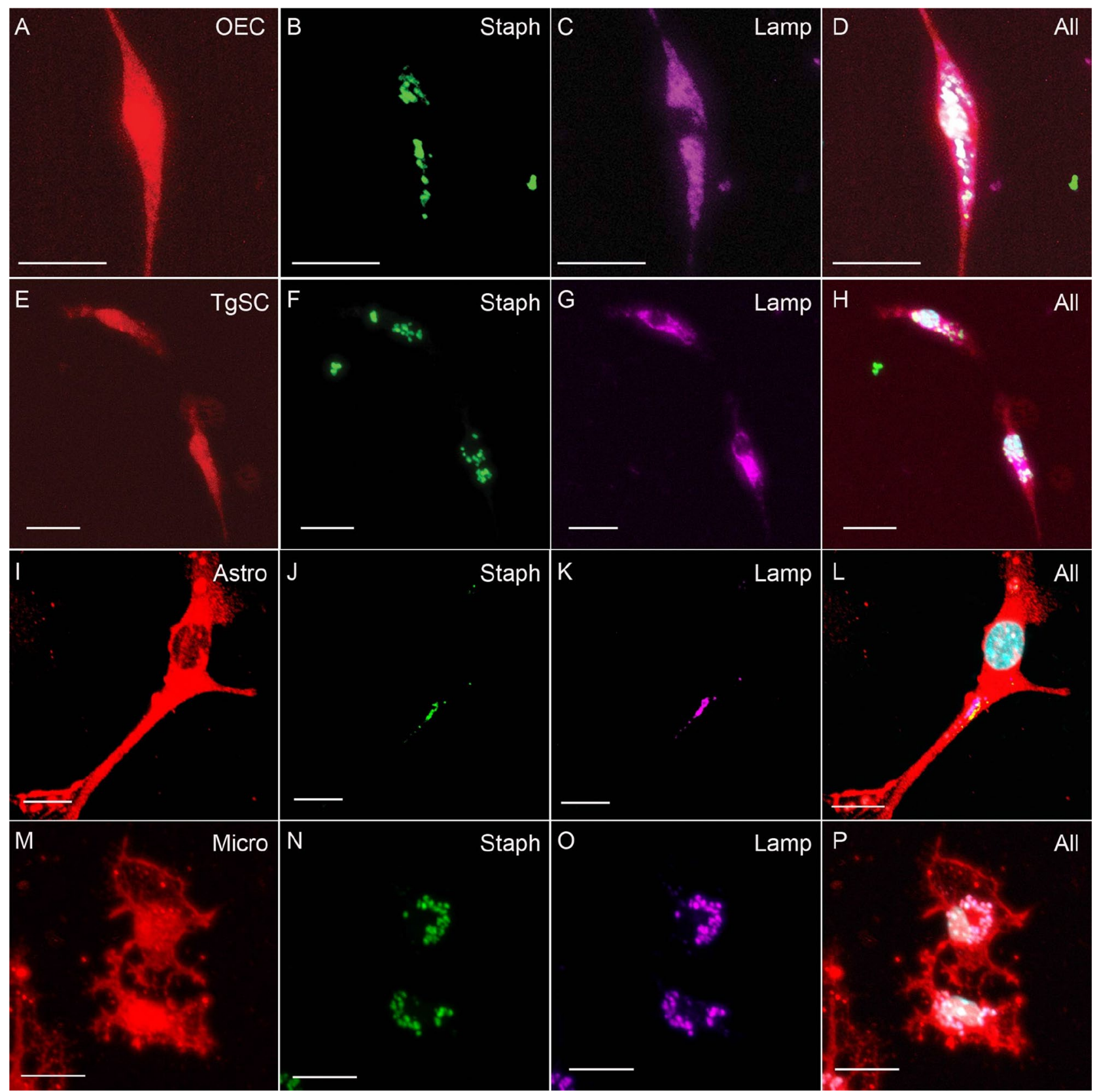

Figure 3. Phagocytosis of $S$. aureus in phagolysosomes in different glial cells. Panels show primary cultures of OECs (A-D), TgSCs (E-H), astrocytes (I-L) and microglia (M-P) from S100ß-DsRed mice. For OECs and TgSCs, red labelling shows DsRed; for astrocytes, red labelling shows GFAP (these cells express low levels of DsRed); for microglia, red labelling shows Iba-1 and Hoechst for nucleus staining. (B,F,J,N) shows $S$. aureus within cells, $(\mathbf{C}, \mathbf{G}, \mathbf{K}, \mathbf{O})$ LAMP-2 stain for lysosomes. S. aureus colocalizes with LAMP-2 stains showing the bacteria is internalized in phagolysosomes. Scale bar: $20 \mu \mathrm{m}$.

interferon $\gamma$ (IFN- $\gamma$ ) and tumour necrosis factor $\alpha$ (TNF- $\alpha$ ), with levels of IFN- $\gamma$ being high in microglia than TNF- $\alpha$ and lower than those for OECs; TgSCs and astrocytes (Fig. 5A-H). The cells also responded to S. aureus with secretion of interleukin 6 (IL-6), and the anti-inflammatory and immune-regulatory cytokine interleukin 10 (IL-10). The amount of IL-6 was consistently higher than the amount of IL-10 (Fig. 5) in OECs, TgSCs and astrocytes; in contrast microglia expressed higher IL-10 than IL-6. Microglia produced significantly higher levels of IFN- $\gamma$ and IL-10, TgSCs showed significantly higher levels of TNF- $\alpha$ and IL-6, than the other glial types, with some variations between time-points (Fig. 5 and Table 1). Overall, production of TNF- $\alpha$ by OECs, TgSCs and astrocytes peaked at $6 \mathrm{~h}$ post exposure and for microglia at $1 \mathrm{~h}$. The levels of IFN- $\gamma$ and IL-10 were highest at 1 $\mathrm{h}$ for microglia as compared to OECs, TgSCs and astrocytes and continued till $24 \mathrm{~h}$. Whilst the levels of IFN- $\gamma$, IL-6 and IL-10 were highest at $24 \mathrm{~h}$ for OECs, TgSCs and astrocytes.

The glia also produced chemokines, including high levels of CXCL1, monocyte chemoattractant protein 1 (MCP-1), macrophage inflammatory proteins $1 \alpha$ and $\beta$ (MIP-1 $\alpha$, MIP-1 $\beta$ ), regulated upon activation-normal 

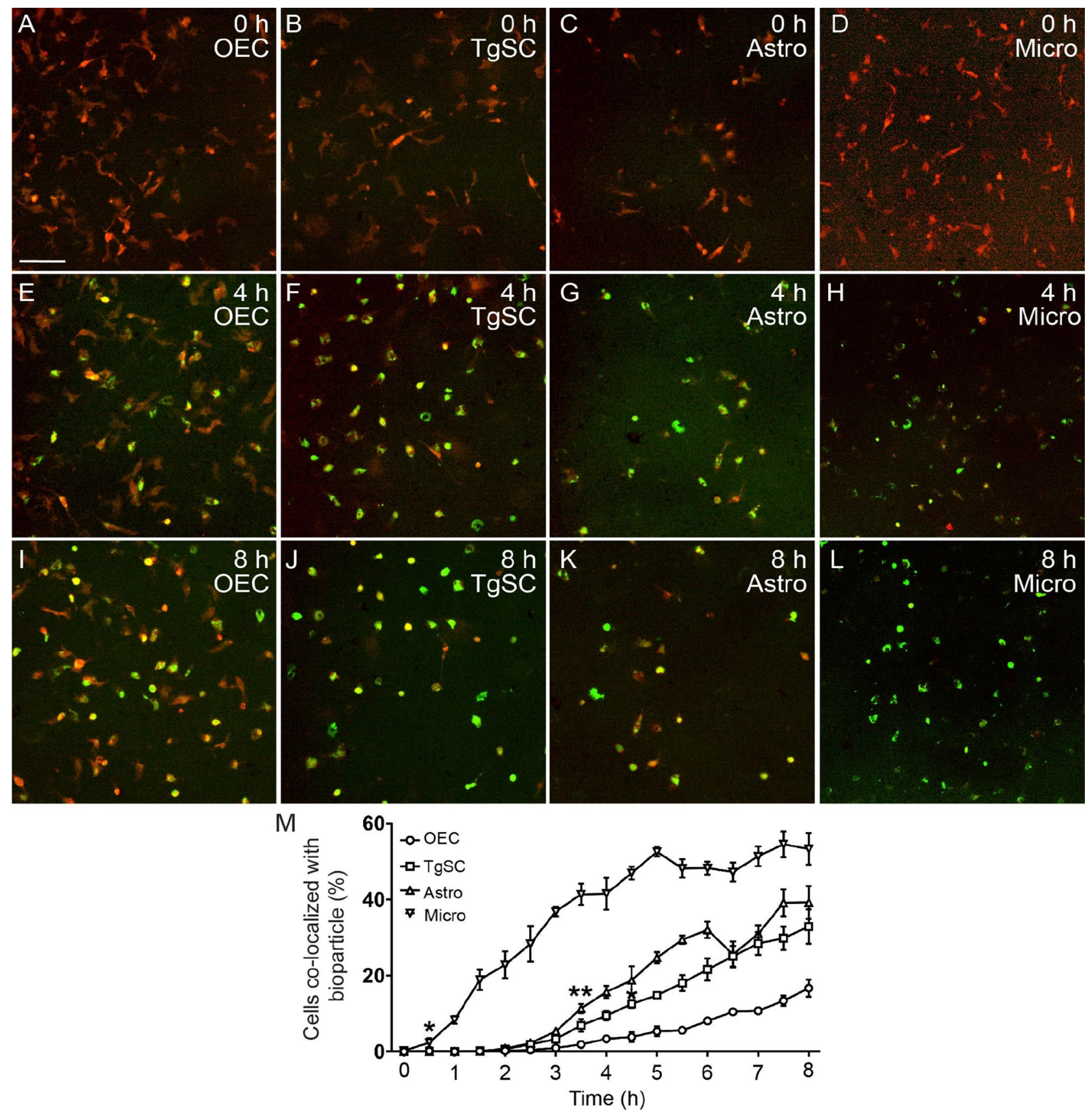

Figure 4. Phagocytosis of pHrodo S. aureus BioParticles by different glial cell types. (A-L) Images show fluorescent $S$. aureus BioParticles (which exhibit green fluorescence when inside lysosomes) co-localized with the glia (red; primary cultures from S100 $\beta$-DsRed mice) at $4 \mathrm{~h}$ and $8 \mathrm{~h}$ post exposure. Since this is a live-cell assay, astrocytes (Astro) and microglia (micro) could not be immunolabeled and had to be identified based on their (weak) expression of DsRed. (M) Time-course of phagocytosis assay showing the percentage of glia that contained phagocytosed fluorescent $S$. aureus BioParticles at different time-points. Significant difference was observed at $30 \mathrm{~min}$ between micro and other glial cells, $3.5 \mathrm{~h}$ between Astro and OEC, at $4.5 \mathrm{~h}$ between TgSC and OEC. Data show mean $\pm S E M,{ }^{*} p \leq 0.05,{ }^{* *} p \leq 0.01$, two-way ANOVA with Tukey's multiple comparison test, $\mathrm{n}=3$ biological replicates $\times 4000$ cells per well. Scale bar: $100 \mu \mathrm{m}$.

T cell expressed and presumably secreted (RANTES) and low levels of eotaxin, in response to $S$. aureus challenge for OECs, TgSCs and astrocytes (Fig. 6). The levels of all these chemokines increased gradually over time from 1 to $24 \mathrm{~h}$ in OECs, TgSCs and astrocytes (Fig. 6). Overall, TgSCs produced higher levels of chemokines than astrocytes, which in turn secreted higher levels than OECs (with individual variations depending on chemokine and/or time-point) (Table 1). Microglia showed high levels of eotaxin as compared to OECs, TgSCs and astrocytes all throughout the time points. Eotaxin, MIP-1 $\beta$ and MCP- 1 all were significantly high at $1 \mathrm{~h}$ for microglia then decreased at $6 \mathrm{~h}$ and increased again at $24 \mathrm{~h}$ (Fig. 6). 

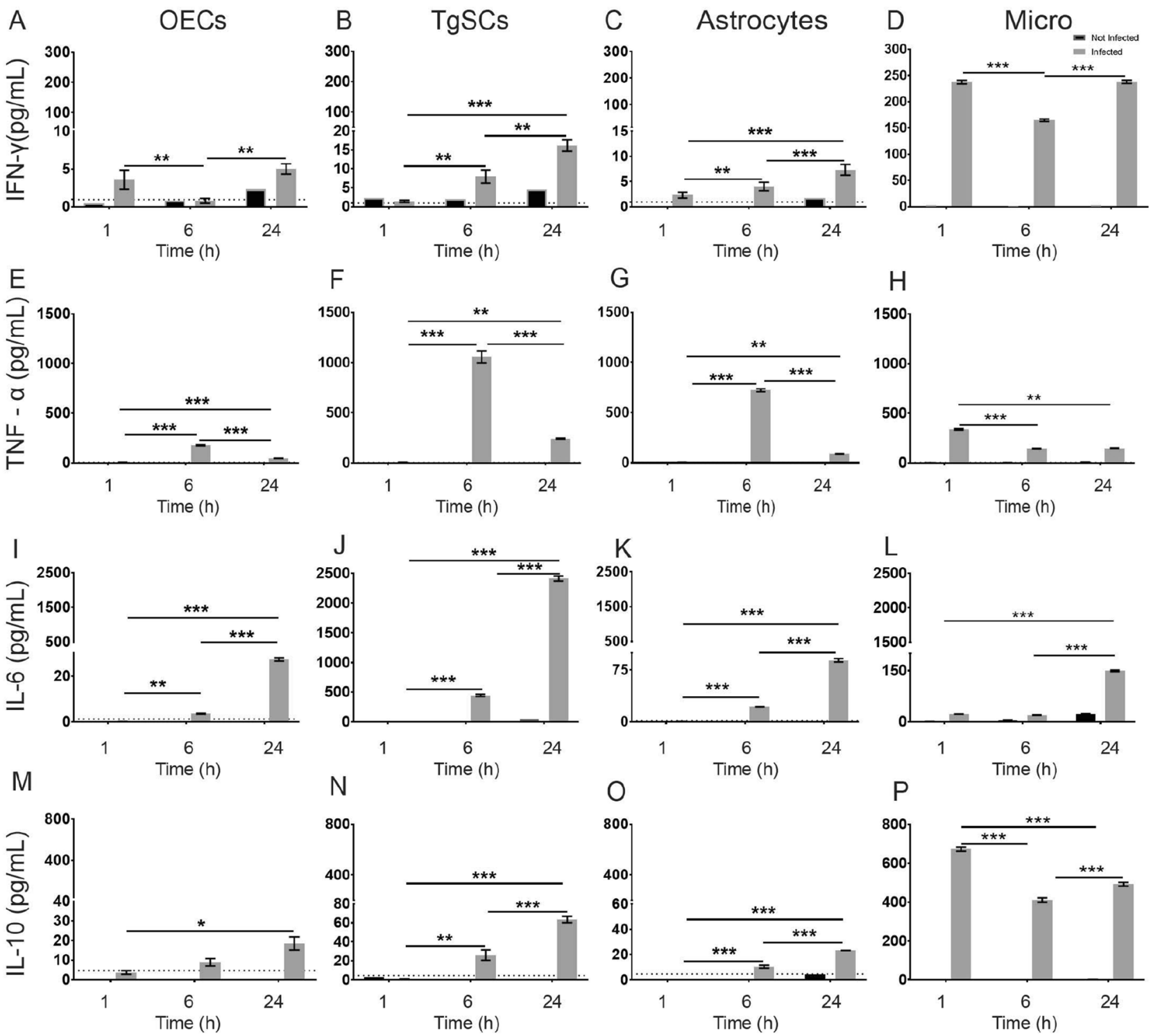

Figure 5. Cytokine responses in glia post S. aureus infection. Cytokine production by OECs, TgSCs, astrocytes and microglia were measured using multiplex ELISA at $1 \mathrm{~h}, 6 \mathrm{~h}$ and $24 \mathrm{~h}$ post exposure to $S$. aureus. The graphs show the amount of the pro-inflammatory cytokines IFN- $\gamma(\mathbf{A}-\mathbf{D})$, TNF- $\alpha(\mathbf{E}-\mathbf{H})$, and IL-6 (I-L) and regulatory cytokine IL-10 (M-P). Data shows mean \pm SEM. $\left({ }^{*} p \leq 0.05,{ }^{* *} p \leq 0.01,{ }^{* *} p \leq 0.001\right.$ (two-way ANOVA with Tukey's multiple comparison test), $\mathrm{n}=2$ technical replicates $(100,000$ cells/well).

\section{Discussion}

Certain pathogens can enter the CNS via the nerves extending between the nasal cavity and the brain (the olfactory and trigeminal nerves) ${ }^{2}$. S. aureus is one of these microbes and can rapidly invade the brain (olfactory bulb) after injury to the nasal epithelium ${ }^{12,13}$. Previous studies have shown that the glia of the olfactory nerve, olfactory ensheathing cells (OECs), respond to $S$. aureus by nuclear translocation of NFkB accompanied by $\mathrm{NO}$ and nitrite production ${ }^{12}$. Capacity for intracellular survival inside OECs and/or TgSCs has previously been shown for Streptococcus pneumoniae $e^{31}$, B. pseudomallei ${ }^{24}$ and Neisseria meningitidis ${ }^{32}$, which can also invade the CNS via the olfactory and/or trigeminal nerves. The aim of the current study was to build on these previous findings to better understand how glia in the olfactory and trigeminal nerve, as well as astrocytes and microglia are affected by $S$. aureus infection.

We showed that $S$. aureus could adhere to and become internalized into all four glial types, over $24 \mathrm{~h}$, but found differences between the capacities for intracellular survival between glia. Intracellular survival was significantly higher in astrocytes than in microglia, OECs and TgSCs, suggesting that peripheral nerve glia and microglia (a professional phagocyte) show better capacity for killing intracellular bacteria than astrocytes. Microglia internalised the $S$. aureus into the perinuclear region within $1 \mathrm{~h}$ of exposure to the bacteria. In contrast, OECs, TgSCs and astrocytes took longer to accumulate the bacteria in the perinuclear region. However, even at $24 \mathrm{~h}$ astrocytes appeared to have bacteria still within cell processes. This was reflected in the intracellular survival 

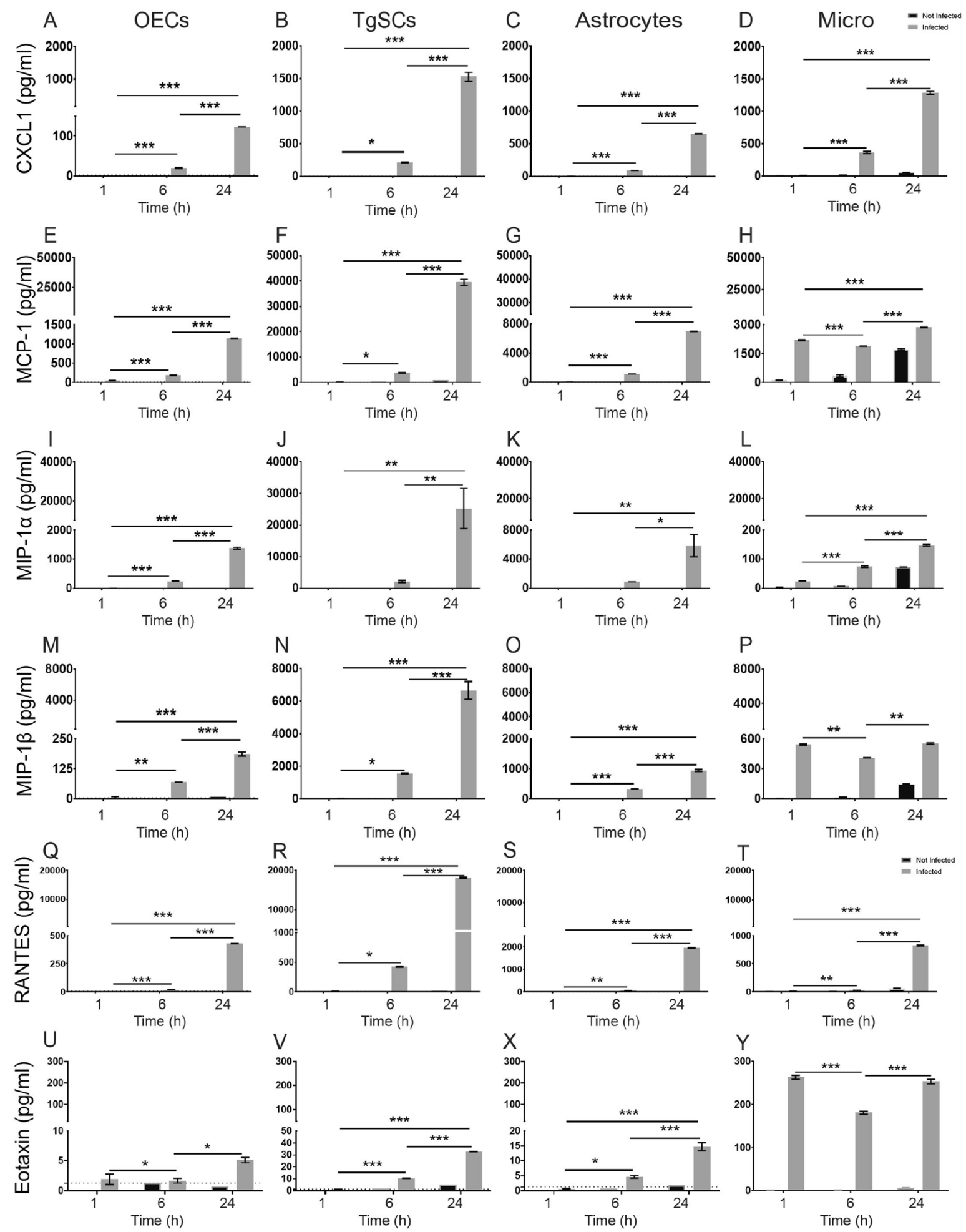

Figure 6. Production of chemokines by the different glial types following exposure to $S$. aureus. Chemokine production by OECs, TgSCs, astrocytes and microglia were measured using multiplex ELISA at $1 \mathrm{~h}, 6 \mathrm{~h}$ and 24 $\mathrm{h}$ post exposure to $S$. aureus. CXCL-1(A-D), MCP-1 (E-H), MIP-1 $\alpha(\mathbf{I}-\mathbf{L})$, MIP-1 $\beta$ (M-P), RANTES (Q-T) and Eotaxin (U-Y). Data shows mean \pm SEM. ${ }^{\star} p<0.05,{ }^{* *} p<0.01,{ }^{* * *} p<0.001$ (two-way ANOVA with Tukey's multiple comparison test), $\mathrm{n}=2$ technical replicates $(100,000$ cells/well). 


\begin{tabular}{|c|c|c|c|c|c|c|c|c|c|c|c|}
\hline Cytokine & Time & $\begin{array}{l}\text { OEC (pg/ } \\
\mathrm{mL})\end{array}$ & $\operatorname{TgSC}(\mathrm{pg} / \mathrm{mL})$ & Astro $(\mathrm{pg} / \mathrm{mL})$ & $\begin{array}{l}\text { Micro (pg/ } \\
\mathrm{mL})\end{array}$ & \begin{tabular}{|l|} 
OEC $v s$ \\
$\operatorname{TgSC}$
\end{tabular} & $\begin{array}{l}\text { OEC } v s \\
\text { Astro }\end{array}$ & $\begin{array}{l}\text { TgSCs } v s \\
\text { Astro }\end{array}$ & \begin{tabular}{|l} 
OEC vs \\
Micro
\end{tabular} & $\begin{array}{l}\text { TgSC vs } \\
\text { Micro }\end{array}$ & \begin{tabular}{|l} 
Astro vs \\
Micro
\end{tabular} \\
\hline \multirow[t]{3}{*}{ IFN- $\gamma$} & $1 \mathrm{~h}$ & $3.6 \pm 1.3$ & $1.4 \pm 0.3$ & $2.3 \pm 0.6$ & $237.5 \pm 3.5$ & ns & ns & ns & $* * *$ & $* * *$ & $* * *$ \\
\hline & $6 \mathrm{~h}$ & $0.8 \pm 0.3$ & $8.0 \pm 1.7$ & $4.0 \pm 0.8$ & $164.7 \pm 2.4$ & $* * *$ & ns & * & $* * *$ & $* * *$ & $* * *$ \\
\hline & $24 \mathrm{~h}$ & $5.0 \pm 0.7$ & $16.2 \pm 1.5$ & $7.3 \pm 1.1$ & $238.1 \pm 3.1$ & $* * *$ & ns & $* * *$ & $* * *$ & $* * *$ & $* * *$ \\
\hline \multirow[t]{3}{*}{ TNF- $\alpha$} & $1 \mathrm{~h}$ & $5.2 \pm 1.1$ & $7.6 \pm 1.3$ & $5.2 \pm 0.2$ & $336.2 \pm 7.1$ & ns & ns & ns & $* * *$ & $* * *$ & $* * *$ \\
\hline & $6 \mathrm{~h}$ & $176.8 \pm 5.1$ & $1056.7 \pm 60.6$ & $722.5 \pm 14.3$ & $143 \pm 4.2$ & $* * *$ & $* * *$ & $* * *$ & ns & $* * *$ & $* * *$ \\
\hline & $24 \mathrm{~h}$ & $44.1 \pm 0.9$ & $242.8 \pm 4.5$ & $88.5 \pm 1.1$ & $147 \pm 4.2$ & $* * *$ & ns & $* * *$ & $* * *$ & $* * *$ & ns \\
\hline \multirow[t]{3}{*}{ IL-6 } & $1 \mathrm{~h}$ & $0.1 \pm 0.1$ & $6.4 \pm 0.2$ & $0.2 \pm 0.1$ & $22.2 \pm 0.2$ & ns & ns & ns & ns & ns & ns \\
\hline & $6 \mathrm{~h}$ & $3.5 \pm 0.1$ & $442.8 \pm 19.2$ & $21.2 \pm 0.2$ & $19.3 \pm 0.5$ & $* * *$ & ns & $* * *$ & ns & $* * *$ & ns \\
\hline & $24 \mathrm{~h}$ & $27.3 \pm 0.7$ & $2412.3 \pm 42.5$ & $89.0 \pm 2.5$ & $149.4 \pm 2.1$ & $* * *$ & $* *$ & $* * *$ & $* * *$ & $* * *$ & $* *$ \\
\hline \multirow[t]{3}{*}{ IL-10 } & $1 \mathrm{~h}$ & $3.7 \pm 0.9$ & $0.4 \pm 0.4$ & 0 & $673.2 \pm 11.0$ & ns & ns & ns & $* * *$ & $* * *$ & $* * *$ \\
\hline & $6 \mathrm{~h}$ & $8.9 \pm 1.9$ & $26.0 \pm 5.4$ & $10.4 \pm 1.1$ & $410.4 \pm 11.6$ & $* * *$ & ns & $* * *$ & $* * *$ & $* * *$ & $* * *$ \\
\hline & $24 \mathrm{~h}$ & $18.5 \pm 3.4$ & $63.5 \pm 3.3$ & $23.1 \pm 0.1$ & $492.2 \pm 9.7$ & $* * *$ & ns & $* * *$ & $* * *$ & $* * *$ & $* * *$ \\
\hline \multirow[t]{3}{*}{ CXCL-1 } & $1 \mathrm{~h}$ & 0 & 0 & $0.6 \pm 0.6$ & $8.8 \pm 0.3$ & ns & ns & ns & ns & ns & ns \\
\hline & $6 \mathrm{~h}$ & $20.4 \pm 1.2$ & $212.0 \pm 8.1$ & $87.9 \pm 0.2$ & $368.6 \pm 15.9$ & $* * *$ & ns & $* * *$ & $* * *$ & $* * *$ & $* * *$ \\
\hline & $24 \mathrm{~h}$ & $123.1 \pm 0.3$ & $1527.7 \pm 69.2$ & $652.0 \pm 4.0$ & $1285 \pm 21.7$ & $* * *$ & $* * *$ & $* * *$ & $* * *$ & $* * *$ & $* * *$ \\
\hline \multirow[t]{3}{*}{ MCP-1 } & $1 \mathrm{~h}$ & $50.0 \pm 4.5$ & $234.1 \pm 5.5$ & $52.1 \pm 6.6$ & $2197 \pm 21.1$ & ns & ns & ns & $* * *$ & $* * *$ & $* * *$ \\
\hline & $6 \mathrm{~h}$ & $179.4 \pm 7.4$ & $3806.9 \pm 150.9$ & $1139.0 \pm 13.7$ & $1877 \pm 16.2$ & $* * *$ & ns & $* * *$ & $* *$ & $* * *$ & ns \\
\hline & $24 \mathrm{~h}$ & $1145.8 \pm 3.4$ & $39,399.4 \pm 1259.5$ & $6940.4 \pm 35.6$ & $2865 \pm 23.9$ & $* * *$ & $* * *$ & $* * *$ & $* *$ & $* * *$ & $* * *$ \\
\hline \multirow[t]{3}{*}{ MIP-1a } & $1 \mathrm{~h}$ & $2.4 \pm 0.1$ & $5.4 \pm 0.2$ & $3.1 \pm 0.1$ & $24.4 \pm 0.6$ & ns & ns & ns & ns & ns & ns \\
\hline & $6 \mathrm{~h}$ & $240.1 \pm 8.9$ & $2083.6 \pm 361.3$ & $879.1 \pm 31.5$ & $73.4 \pm 2.8$ & ns & ns & ns & ns & ns & ns \\
\hline & $24 \mathrm{~h}$ & $1376.1 \pm 32.3$ & $25,274.2 \pm 6374.0$ & $5865.0 \pm 1529.2$ & $148.1 \pm 3.1$ & $* * *$ & ns & $* * *$ & ns & $* * *$ & ns \\
\hline \multirow[t]{3}{*}{ MIP-1 $\beta$} & $1 \mathrm{~h}$ & $4.4 \pm 4.4$ & $8.8 \pm 0.6$ & 0 & $541.8 \pm 6.1$ & ns & ns & ns & * & * & * \\
\hline & $6 \mathrm{~h}$ & $68.8 \pm 0.8$ & $1544.2 \pm 41.1$ & $333.0 \pm 2.2$ & $411.5 \pm 1.4$ & $* * *$ & ns & $* * *$ & ns & $* * *$ & ns \\
\hline & $24 \mathrm{~h}$ & $186.2 \pm 7.9$ & $6663.1 \pm 535.5$ & $943.6 \pm 4$ & $552.8 \pm 8.1$ & $* * *$ & ** & $* * *$ & ns & $* * *$ & ns \\
\hline \multirow[t]{3}{*}{ RANTES } & $1 \mathrm{~h}$ & 0 & $12.8 \pm 0.5$ & $0.3 \pm 0.3$ & $12.5 \pm 0.2$ & ns & ns & ns & ns & ns & ns \\
\hline & $6 \mathrm{~h}$ & $20.6 \pm 0.5$ & $425.1 \pm 9.0$ & $68.8 \pm 0.4$ & $30.4 \pm 1.2$ & $* * *$ & ns & $* * *$ & ns & $* * *$ & ns \\
\hline & $24 \mathrm{~h}$ & $430.9 \pm 1.8$ & $18,114.8 \pm 141.7$ & $1959.0 \pm 20.9$ & $829.2 \pm 7.3$ & $* * *$ & $* * *$ & $* * *$ & $* * *$ & $* * *$ & $* * *$ \\
\hline \multirow[t]{3}{*}{ Eotaxin } & $1 \mathrm{~h}$ & $1.9 \pm 0.9$ & $1.0 \pm 0.3$ & $0.6 \pm 0.2$ & $263.3 \pm 4.5$ & ns & ns & ns & $* * *$ & $* * *$ & $* * *$ \\
\hline & $6 \mathrm{~h}$ & $1.7 \pm 0.4$ & \begin{tabular}{|l|}
$10.4 \pm 0.2$ \\
\end{tabular} & $4.7 \pm 0.5$ & $181.1 \pm 3.5$ & $* * *$ & $* * *$ & $* *$ & $* * *$ & $* * *$ & $* * *$ \\
\hline & $24 \mathrm{~h}$ & $5.1 \pm 0.5$ & $32.8 \pm 0.2$ & $14.8 \pm 1.4$ & $253.4 \pm 5.4$ & $* * *$ & $* * *$ & $* * *$ & $* * *$ & $* * *$ & $* * *$ \\
\hline
\end{tabular}

Table 1. Cytokine/chemokine secretion by OECs, TgSCs, astrocytes and microglia post $S$. aureus exposure with comparison between the glia. (Data shows mean \pm SEM. (Two-way ANOVA with Tukey's multiple comparison post-hoc test) $\left({ }^{*} p \leq 0.05,{ }^{* *} p \leq 0.01,{ }^{* * *} p \leq 0.001\right.$, ns $=$ not significantly different $)$.

with astrocytes retaining significantly more viable bacteria at $24 \mathrm{~h}$ compared to the other cell types. The different intracellular distribution of bacteria between astrocytes and peripheral glia may hold clues to the higher capacity for intracellular survival of $S$. aureus in astrocytes ${ }^{33}$.

We also compared the time-course of phagocytosis between the different types of glia by exposing the cells to pHrodo-green S. aureus BioParticles, which become fluorescent after internalization into phagolysosomes/ lysosomes, and imaging the cells over time. The results showed that microglia and astrocytes were the first cells to show significant uptake of the BioParticles in phagolysosomes/lysosomes, followed by TgSCs and then OECs. Whilst microglia, the resident macrophage of the brain $^{34}$, were the fastest to take up the BioParticles (30 min to start their immune defence function ${ }^{35}$ ), astrocytes were faster than TgSCs or OECs. Astrocytes have previously been reported to rapidly (within $2 \mathrm{~h}$ ) phagocytose damaged cells and synaptosomes ${ }^{36,37}$. Internalization of bacteria (Streptococcus agalactiae) by astrocytes in vitro has been shown to be slower $(\sim 9 \mathrm{~h})$ and variable between cells ${ }^{38}$. Thus, it is possible that the time-course of BioParticle internalization into astrocytes may vary depending on the type of cargo (cell debris versus bacteria, as well as bacterial species). Previous studies have shown that OECs respond to the presence of cell debris by extending filopodia within 15 min of exposure and to internalize axonal debris within $4 \mathrm{~h}$ of exposure ${ }^{11}$. OECs and TgSCs can internalize E. coli bacteria $6 \mathrm{~h}$ post exposure $^{16}$. The timing of these responses is relatively similar to the time-course for phagocytosis of $S$. aureus by OECs and TgSCs reported in the current study. To the best of our knowledge, the invasion frequency (percentage of attached bacteria that end up inside the cell) has not been compared between glia for any bacterial species, previously. These findings show that OECs, TgSCs, astrocytes and microglia all can respond to bacteria and bacteria-conjugated BioParticles, which are internalized into phagolysosomes within 1-4 h, with some differences between cell types regarding the percentages of cells internalizing the cargo. This time-course is similar to what has previously been reported for microglia/macrophages, which respond to bacteria and PAMPs ${ }^{14}$ and phagocytose bacteria-conjugated BioParticles in less than $1 \mathrm{~h}^{35}$ as shown in our results too.

All glia responded to $S$. aureus with secretion of multiple cytokines and chemokines. Interestingly, production of these was overall highest in microglia and TgSCs, followed by astrocytes and then OECs. This does not 
match the fact that $S$. aureus exhibits stronger capacity for intracellular survival in astrocytes than in OECs/ TgSCs, suggesting that other inflammatory mediators than cytokines are involved in differential innate immune responses between peripheral glia and astrocytes.

We found all four glial cell types rapidly responded to $S$. aureus by secretion of TNF- $\alpha$ (with the highest levels being produced by TgSCs). Production of TNF- $\alpha$ by these cells after $S$. aureus exposure is in alignment with a previous study, in which bacterial invasion of the olfactory nerve and bulb by $S$. aureus after epithelial injury resulted in increased levels of TNF- $\alpha$ in primary olfactory nervous system tissue ${ }^{13}$. One previous study has also shown that astrocytes can produce TNF- $\alpha$ in response to $S$. aureus ${ }^{39}$. TNF- $\alpha$ is a critical component of the innate immune response against $S$. aureus brain abscess ${ }^{39}$, but as it is a pro-inflammatory cytokine, it can also cause damage to brain tissue and death of neurons ${ }^{40}$. TNF- $\alpha$ receptors exist both in neurons and glia, and play an important role in cell death ${ }^{41}$. Due to their location, OECs are often likely exposed to pathogens, and therefore mechanisms must exist that limit damage induced by pro-inflammatory cytokines. OECs and supporting cells of the primary olfactory nervous system produce pituitary adenylate cyclase activating peptide (PACAP $)^{42}$, which protects against TNF- $\alpha$-mediated death of neurons in both the olfactory nerve $\mathrm{e}^{43}$ and brain ${ }^{44}$, and it has previously been suggested that PACAP may be counteracting potential harmful effects of TNF- $\alpha$ as a response to bacteria in the primary olfactory nervous system ${ }^{13}$. PACAP and its receptors are also expressed in the trigeminal nerve ${ }^{45}$. TNF- $\alpha$ expression in microglia was enhanced as early as $1 \mathrm{~h}$ following infection and was elevated up to $24 \mathrm{~h}$ which follows a similar trend as shown in a previous study ${ }^{21}$. We also found that the glia secreted another pro-inflammatory cytokine, IFN- $\gamma$, in response to $S$. aureus, at very high levels in microglia and at low levels for the other glial cells. In CNS injury, low levels of IFN- $\gamma$ can induce neuroprotective functions by microglial cells. At high concentrations of IFN- $\gamma$, however, this neuroprotective effect decreases ${ }^{46}$. This was the case in microglia which produced high levels of IFN- $\gamma$ and positive results for all other 23 cytokines (Supplementary Table 2).

All glia also produced regulatory cytokines IL-6 and IL-10 in response to S. aureus; this response was significantly delayed compared to TNF- $\alpha$. Production of IL- 6 by OECs ${ }^{13}$ and astrocytes ${ }^{39}$ responding to S. aureus has previously been shown. IL-6 plays a central role in cellular responses to nerve injury and is important for regeneration and cell survival ${ }^{47,48}$. IL- 6 has been suggested to prevent cell death of OECs ${ }^{13}$ as activation of IL-6 can stimulate anti-apoptotic pathways and the IL-6 receptor is upregulated in OECs after neuronal injury ${ }^{49}$. $B$. pseudomallei, another bacterium that can invade the olfactory and trigeminal nerves, also stimulates production of IL- 6 and TNF- $\alpha$ in $\mathrm{OECs}^{50}$. IL-10 is a potent anti-inflammatory cytokine ${ }^{51,52}$ that can inhibit TNF- $\alpha$ production, thus regulating potential damaging effects of TNF- $\alpha$ on tissue ${ }^{53}$. This is observed in microglia with high level of IL-10 production corresponding to low level of TNF- $\alpha$ at different time points. At 24 h post exposure to S. aureus, the high level of IL-10 in OECs, TgSCs, astrocytes and microglia, correlated with significantly reduced levels of TNF- $\alpha$ compared to different time points, perhaps suggesting that IL-10 reduced TNF- $\alpha$ secretion.

We found that $S$. aureus triggered production of several chemokines (chemotactic cytokines), CXCL-1, MCP1, MIP-1 $\alpha$, MIP-1 $\beta$ and RANTES, and Eotaxin. OECs, but not TgSCs, have previously been demonstrated to respond to E. coli and PAMPs by CXCL-1 secretion ${ }^{14}$, which is demonstrated to be critical for neutrophildependent bacterial elimination via induction of reactive oxygen species and reactive nitrogen species ${ }^{54}$. Astrocytes have also been shown to secrete MIP-1, MCP- 2 and MIP- $1 \beta$ in response to S. aureus ${ }^{39}$. These chemokines are part of the main group of cytokines attracting different populations of leukocytes, (preferentially monocytes, macrophages, eosinophils and subsets of lymphocytes) and play important roles in inflammatory responses against pathogens ${ }^{55,56}$. The level of MCP-1 has been shown to be increased in cerebrospinal fluid during pyogenic and tuberculous meningitis and may thus be a common responder of CNS cells to bacterial infection ${ }^{57}$. MCP-1 levels are also increased in plasma in meningococcal disease ${ }^{58}$. Microglia under non-activated conditions produce numerous cytokines such as MIP-1 $\alpha$, MIP- $1 \beta$ and MCP- $1^{59}$ and we observed this at $24 \mathrm{~h}$ in the non-infected microglia.

It has previously been shown ${ }^{59}$ that microglia release a powerful immune response when activated. OECs and astrocytes, but not Schwann cells, mount a similar immune response to E. coli and PAMPs ${ }^{14}$. OECs and astrocytes have also been found to express higher levels of mRNA for innate immune factors than Schwann cells in a microarray study ${ }^{60}$. In contrast to these findings, we found that all glial cells (TgSCs, OECs, astrocytes and microglia) could all internalize and phagocytose S. aureus / S. aureus BioParticles, and that all four glial types responded to $S$. aureus with secretion of many cytokines and chemokines; in fact, microglia and TgSCs consistently secreted higher amounts of cytokines and chemokines than the other glia. In the previous study ${ }^{60}$, the Schwann cells were derived from the sciatic nerve and brachial plexus. Here, we used trigeminal nerve Schwann cells, which may have evolved to exhibit a more powerful immune response to pathogens than other Schwann cells, as the trigeminal nerve is likely to be more often exposed to microbes than other peripheral nerves.

Due to their unique growth-promoting properties, and because they can be relatively easy isolated from the roof of the nasal cavity, transplantation of OECs is emerging as a promising therapy for spinal cord injury repair $^{2,61,62}$. The innate immune functions of OECs are very important in this context, due to the inflammatory environment of the spinal cord injury site (which in turn varies depending on time post-injury). Depending on the activation state of OECs, they may secrete cytokines that are pro-inflammatory or regulatory and thus have both detrimental and beneficial effects ${ }^{12,14}$. The fact that OECs secreted lower levels of pro-inflammatory cytokines than the other glia indicate that OECs could have immunomodulatory functions, as has been suggested previously ${ }^{63}$. The capacity for phagocytosis by transplanted OECs is also likely beneficial, as the cells can help clear cell debris present at the injury site. Compounds that can stimulate the phagocytic activity of OECs without causing a strong pro-inflammatory response have been suggested to potentially increase the therapeutic potential of these cells ${ }^{64-68}$. Thus, it is important to characterise which cytokines are expressed by OECs under various conditions.

In conclusion, these results have demonstrated that OECs, TgSCs, astrocytes and microglia can phagocytose S. aureus. Whilst the glia mounted an innate immune response, live bacteria could still be isolated from cells after 
24 h. OECs, TgSCs (PNS) and microglia (CNS) showed stronger capacity for killing of intracellular S. aureus than astrocytes, however, OECs secreted the lowest amounts of both pro- and anti-inflammatory cytokines in response to bacteria, potentially suggesting an immunomodulatory function of these cells.

\section{Materials and methods}

Primary glia culture. Glia cultures were obtained from S100 $\beta$-DsRed transgenic mice according to previously described methods ${ }^{69}$. Briefly, the olfactory bulb and trigeminal nerve were dissected out for preparations of OECs and TgSCs, respectively, from postnatal day seven pups. Tissue explants were plated into the wells of polystyrene 24-well plates, pre-coated with Matrigel basement membrane matrix (Corning Matrigel Basement Membrane Matrix, FAL354234). The explants were maintained in glial medium, constituting of Dulbecco's Modified Eagle Medium (DMEM), 10\% foetal bovine serum (FBS) and gentamicin (Gibco $50 \mathrm{mg} / \mathrm{mL}$ ), supplemented with GlutaMAX and G5 (both Gibco, added according to the manufacturer's instructions), at $37^{\circ} \mathrm{C}$ with $5 \% \mathrm{CO}_{2}$. Cells were cultured to $80 \%$ confluency after which they were trypsinized (using Gibco TrypLE Express, 1X) and used for experiments. Primary OEC cultures were $>70 \%$ pure and TgSCs cultures were $>80 \%$ pure (based on DsRed expression) (Supplementary Fig. 1 and Supplementary Table 1).

Primary astrocytes were obtained from postnatal day three pups following a previous published $\operatorname{protocol}^{70}$. The brain was removed from the cranium, the olfactory bulb and cerebellum were removed. Careful removal of meninges was performed to avoid contamination of fibroblasts and meningeal cells. Forebrain was carefully separated from midbrain containing major cerebral vessels to avoid endothelial contamination. It was then cut into four smaller pieces followed by trypsinization. The cell suspension was plated in a poly-D-lysine hydrobromide (Sigma-Aldrich P6407)-coated T75 flask. After seven to eight days (90\% confluency), astrocytes were separated from microglia (as overlaying microglia sit exposed) by shaking on an orbital shaker at $180 \mathrm{rpm}$ for 30 $\mathrm{min}$. Oligodendrocyte precursor cells were next removed by shaking the flask at $240 \mathrm{rpm}$ for $6 \mathrm{~h}$. The remaining astrocytes were trypsinized (using Gibco TrypLE Express) and used for experiments. Primary astrocyte cultures were $>70 \%$ pure (based on GFAP immunostaining) (Supplementary Fig. 1 and Supplementary Table 1).

Primary microglia were prepared from postnatal day 3 (P3) S100ß-DsRed transgenic mice following a previous published protocol ${ }^{71}$. The entire brain cell population was isolated from the brain tissue by enzymatic digestion and mechanical dissociation using Neural Tissue Dissociation Kit with GentleMACS (Miltenyi Biotec,130-093-231). The cell pellet consisting of a mixture of all brain cells was further subjected to magnetic cells sorting for microglia enrichment using CD11b/c microbeads (Miltenyi Biotec,130-093-636) according to manufacturer protocol. The different glial preparations were separately plated in plastic 24 -well plates and maintained in glial medium containing Dulbecco's Modified Eagle Medium with $10 \%$ foetal bovine serum (FBS), gentamycin (Gibco, $50 \mathrm{mg} / \mathrm{mL}$ ) and GlutaMAX at $37^{\circ} \mathrm{C}$ with $5 \% \mathrm{CO}_{2}$ for 5 days. Cells were replated into T-25 flasks and allowed to proliferate to $80 \%$ confluency then trypsinized (using Gibco TrypLE Express) and used for experiments. Primary microglia cultures were $>85 \%$ pure (based on Iba-1 immunostaining) (Supplementary Fig. 1 and Supplementary Table 1).

Bacterial strain and culture conditions. Staphylococcus aureus (ATCC 29213) cultures were grown, from a sterile loop inoculum from a glycerol stock, in liquid Brain Heart Infusion (BHI) broth, at $37^{\circ} \mathrm{C}$ in a shaking incubator (180-200 rpm) for 14-18 $\mathrm{h}^{72}$. After overnight incubation, the bacterial culture was centrifuged at $10,000 \mathrm{~g}$ for $10 \mathrm{~min}$ at $20^{\circ} \mathrm{C}$. The supernatant was removed, and the bacterial pellet was washed with sterile phosphate buffered saline (PBS). The washing step was repeated twice before resuspending the bacteria in antibioticfree medium (DMEM, 10\% FBS and GlutaMAX) for experiments. Bacterial concentration was determined by plating on BHI agar plates overnight, after which the number of colony-forming units (CFU) was determined.

In vitro infection assay. To analyse the interaction of $S$. aureus with glia, we exposed primary OEC, TgSCs, astrocytes and microglia to the bacteria. Glia were seeded in 96-well plates at 4000 cells per well and incubated at $37^{\circ} \mathrm{C}$ in $5 \% \mathrm{CO}_{2}$ until approximately $80 \%$ confluence. Monolayers were then washed and infected with S. aureus diluted in antibiotic-free medium at a multiplicity of infection (MOI) of 100:1 ${ }^{73}$ or to medium alone (control) for $1 \mathrm{~h}$. Adhesion of $S$. aureus to glia was determined at $1 \mathrm{~h}$ post exposure by washing monolayers with PBS to remove unattached bacteria, after which adherent bacteria was enumerated by CFU counts on BHI agar ${ }^{74}$. To determine the number of $S$. aureus CFU that have been internalised into the cells, cells were lysed using $0.05 \%$ Triton X (Sigma-Aldrich Triton X-100 laboratory grade) for 2-3 min followed by mixing with PBS and serial ten-fold dilution of the lysate. After which bacterial counts were determined on BHI agar.

To determine invasion and survival frequency of the cells, the cells were exposed to $1 \mathrm{~h}$ bacterial inoculation after which the cells were washed at $1 \mathrm{~h}, 6 \mathrm{~h}$ or $24 \mathrm{~h}$ with PBS and antibiotic protection media to kill extracellular bacteria. Antibiotic protection media contained penicillin $250 \mathrm{U} / \mathrm{mL}$, streptomycin $250 \mathrm{U} / \mathrm{mL}$ (from stock Gibco Penicillin-Streptomycin, 10,000 U/mL) and gentamicin (Gibco, $50 \mathrm{mg} / \mathrm{mL}$ ). Bacterial load was determined by lysing the cells and determining CFUs on BHI agar. Invasion frequency in \% was determined by comparing bacterial invasion of each glial cell type between $6 \mathrm{~h}$ post exposure and $1 \mathrm{~h}$ post exposure using the following formula:

$$
\% \text { invasion frequency }=\frac{\text { Bacterial load at } 6 \mathrm{~h} \text { post exposure }}{\text { Bacterial load at } 1 \mathrm{~h} \text { post exposure }} \times 100
$$

Similarly, data from bacterial load at $24 \mathrm{~h}$ post exposure and $6 \mathrm{~h}$ post exposure was used to calculate intracellular survival, according to the following formula: 


$$
\% \text { intracellular survival }=\frac{\text { Bacterial load at } 24 \mathrm{~h} \text { post exposure }}{\text { Bacterial load at } 6 \mathrm{~h} \text { post exposure }} \times 100
$$

Phagocytosis assay. To compare the capability for phagocytosis between the different types of glia, we exposed primary OEC, TgSCs, astrocytes and microglia to pHrodo Green S. aureus Bioparticles Conjugate (Invitrogen) and studied internalization into lysosomes over time using live-cell imaging. Glia were seeded in 96-well plates at 4000 cells per well (in normal culture medium, DMEM, 10\% FBS, gentamicin, GlutaMAX) and incubated at $37^{\circ} \mathrm{C}$ in $5 \% \mathrm{CO}_{2}$. The bioparticles were added to each well (final concentration: $10 \mu \mathrm{g} / \mathrm{mL}$ ) from a stock solution of $1 \mathrm{mg} / \mathrm{mL}$ and live cell imaging was performed (red and green channels for DsRed cells with green bioparticles).

Immunofluorescence. Glia seeded in 96-well plates at 4000 cells per well were fixed with $4 \%$ paraformaldehyde (PFA) for $10 \mathrm{~min}$ and then rinsed with PBS three times, at various time points. Further, blocking/permeabilising solution (3\% bovine serum albumin in PBS with $0.3 \%$ Triton X-100) was added for 30 min at room temp on a shaker. Primary antibody, rabbit or mouse anti-S. aureus antibody (1:800, Abcam, ab20920) or goat anti-glial fibrillary acidic protein (GFAP) antibody (1:400, Abcam, ab53554) or rabbit ionized calcium-binding adaptor protein-1 (IBA-1) antibody (1:100, Abcam, ab178847) or Anti-LAMP2 antibody [GL2A7] (1:800, Abcam, ab13524) was added and kept at $4{ }^{\circ} \mathrm{C}$ overnight on a rocking shaker. The following day, plates were washed with PBS three times and secondary antibodies were added. These were donkey anti-rabbit IgG (highly cross-adsorbed), conjugated to Alexa Fluor 488 (1:500; Thermo Fisher Scientific, A21206), or donkey anti-goat IgG (pre-adsorbed) H\&L (heavy and light chains), conjugated to Alexa Fluor 647 (1:500; Abcam, ab150135) or goat anti-rabbit IgG H\&L (Alexa Fluor 594) preadsorbed (1:500; Abcam, ab150084) or donkey anti-rat IgG H\&L (Alexa Fluor 647) preadsorbed (1:500, Abcam, ab150155) or goat Anti-Rat IgG H\&L (Alexa Fluor 488) (1:500, ab150157) or donkey anti-goat IgG $(\mathrm{H}+\mathrm{L})$ cross-adsorbed secondary antibody, Alexa Fluor 488 (1:500; Thermo Fisher Scientific, A-11055). Cell nuclei were stained with Hoechst (1:5000, Life Technologies).

Imaging. Lower power images were captured on a Nikon Eclipse Ti2 inverted microscope. Higher magnification images were taken using an Olympus FV3000 confocal microscope. Images were colour-balanced using Adobe Photoshop CS5 (Adobe Systems Incorporated) with the entire field of view being altered uniformly. Figures were compiled using Adobe Illustrator CS5 (Adobe Systems Incorporated). For live cell imaging, the IncuCyte Live Cell Analysis Imaging System (Sartorius) was used. Images were taken every $30 \mathrm{~min}$ in the red and green fluorescence channels. Analysis was performed using CellProfiler 3.0 cell image analysis software and NIS-Elements AR 5.200 software. Cell length was measured using the NIS-Elements AR 5.200 software manually, using 15-20 fields of view (FOVs), 10-15 cells per FOV, with three biological and three technical repeats.

Cytokine assay. A set of 23 cytokines were analysed using a highly sensitive antibody-based multiplex cytokine assay kit, the Mouse Cytokine 23-Plex Group 1 kit (Bio-Rad Laboratories). Glia were seeded in 6-well plates at 100,000 cells per well (in antibiotic free culture medium) and incubated at $37^{\circ} \mathrm{C}$ in $5 \% \mathrm{CO}_{2}$. Then the in-vitro assay bacterial protocol was followed till $24 \mathrm{~h}$. Cell culture supernatants were collected, filtered, and centrifuged at $1000 \mathrm{~g}$ for $15 \mathrm{~min}$ at $4^{\circ} \mathrm{C}$. The samples were stored at $-80^{\circ} \mathrm{C}$ until use. On the day of experiment, samples were thawed on ice and diluted with Assay Diluent (from the kit) as directed by the manufacturer. Preparation of standards and assay techniques were followed as per the manufacturer-recommended protocol. All incubation steps were performed on a shaker and washing steps were done using a magnetic plate wash station. The beads were resuspended by shaking the plate vigorously on an orbital shaker, and immediately analysed using a Bio-Plex 200 Multiplex Reader instrument (Bio-Rad Laboratories), following the manufacturersuggested settings. The Bio-Plex Manager Software (Bio-Rad Laboratories) was used for instrument control, data acquisition, and data analysis. The acquired data and graphs (standard curves) were exported into Microsoft Excel and then GraphPad PRISM version 7 (www.graphpad.com/scientific-software/prism) was used for further analysis and preparation of graphs for figures.

Statistical analysis. Statistics and graphical analysis were performed using Microsoft Excel and GraphPad PRISM 7 software. One-way ANOVA with Tukey's multiple comparison post-hoc test or Kruskal-Wallis Test with Dunn's multiple comparison test were used for statistical analysis.

Ethics statement. The study was carried out in compliance with the ARRIVE guidelines. All procedures were approved by Griffith University and the University Animal Ethics Committee (MSC/13/18) under the guidelines of the National Health and Medical Research Council of Australia and in accordance with the Australian Code for the Care and Use of Animals for Scientific Purposes (8th Edition, 2013); and in accordance with the Australian Commonwealth Office of the Gene Technology Regulator.

Received: 2 October 2020; Accepted: 4 May 2021

Published online: 21 May 2021 


\section{References}

1. De Chiara, G. et al. Infectious agents and neurodegeneration. Mol. Neurobiol. 46, 614-638 (2012).

2. Dando, S. J. et al. Pathogens penetrating the central nervous system: infection pathways and the cellular and molecular mechanisms of invasion. Clin. Microbiol. Rev. 27, 691-726. https://doi.org/10.1128/CMR.00118-13 (2014).

3. Graziadei, P. P. \& Monti Graziadei, G. A. Neurogenesis and plasticity of the olfactory sensory neurons. Ann. N. Y. Acad. Sci. 457, $127-142$ (1985).

4. Mackay-Sim, A. \& Kittel, P. W. On the life span of olfactory receptor neurons. Eur. J. Neurosci. 3, 209-215. https://doi.org/10.1111/j. 1460-9568.1991.tb00081.x (1991).

5. Farbman, A. I. Olfactory neurogenesis: genetic or environmental controls?. Trends Neurosci. 13, 362-365. https://doi.org/10.1016/ 0166-2236(90)90017-5 (1990).

6. Schaefer, M. L., Bottger, B., Silver, W. L. \& Finger, T. E. Trigeminal collaterals in the nasal epithelium and olfactory bulb: a potential route for direct modulation of olfactory information by trigeminal stimuli. J. Comp. Neurol. 444, 221-226. https://doi.org/10.1002/ cne.10143 (2002).

7. Jochems, S. P. et al. Innate and adaptive nasal mucosal immune responses following experimental human pneumococcal colonization. J. Clin. Invest. 130, 4523-4538. https://doi.org/10.1172/JCI128865 (2019).

8. Tacchi, L. et al. Nasal immunity is an ancient arm of the mucosal immune system of vertebrates. Nat. Commun. 5, 5205. https:// doi.org/10.1038/ncomms6205 (2014).

9. Su, Z. et al. Olfactory ensheathing cells: the primary innate immunocytes in the olfactory pathway to engulf apoptotic olfactory nerve debris. Glia 61, 490-503. https://doi.org/10.1002/glia.22450 (2013).

10. Wewetzer, K., Kern, N., Ebel, C., Radtke, C. \& Brandes, G. Phagocytosis of O4+ axonal fragments in vitro by p75- neonatal rat olfactory ensheathing cells. Glia 49, 577-587. https://doi.org/10.1002/glia.20149 (2005).

11. Nazareth, L. et al. Olfactory ensheathing cells are the main phagocytic cells that remove axon debris during early development of the olfactory system. J. Comp. Neurol. 523, 479-494. https://doi.org/10.1002/cne.23694 (2015).

12. Harris, J. A., West, A. K. \& Chuah, M. I. Olfactory ensheathing cells: nitric oxide production and innate immunity. Glia 57, 1848-1857. https://doi.org/10.1002/glia.20899 (2009)

13. Herbert, R. P. et al. Cytokines and olfactory bulb microglia in response to bacterial challenge in the compromised primary olfactory pathway. J. Neuroinflam. 9, 109. https://doi.org/10.1186/1742-2094-9-109 (2012).

14. Vincent, A. J., Choi-Lundberg, D. L., Harris, J. A., West, A. K. \& Chuah, M. I. Bacteria and PAMPs activate nuclear factor kappaB and Gro production in a subset of olfactory ensheathing cells and astrocytes but not in Schwann cells. Glia 55, 905-916. https:// doi.org/10.1002/glia.20512 (2007).

15. Leung, J. Y. et al. Olfactory ensheathing cells are attracted to, and can endocytose, bacteria. Cell Mol. Life Sci. 65, 2732-2739. https:// doi.org/10.1007/s00018-008-8184-1 (2008).

16. Panni, P. et al. Phagocytosis of bacteria by olfactory ensheathing cells and Schwann cells. Neurosci. Lett. 539, 65-70. https://doi. org/10.1016/j.neulet.2013.01.052 (2013).

17. Nazareth, L. et al. Novel insights into the glia limitans of the olfactory nervous system. J. Comp. Neurol. 527, 1228-1244. https:// doi.org/10.1002/cne.24618 (2019).

18. Geyer, S., Jacobs, M. \& Hsu, N. J. Immunity against bacterial infection of the central nervous system: an astrocyte perspective. Front Mol. Neurosci. 12, 57. https://doi.org/10.3389/fnmol.2019.00057 (2019).

19. Jung, Y.-J. \& Chung, W.-S. Phagocytic roles of glial cells in healthy and diseased brains. Biomol. Ther. (Seoul) 26, 350-357. https:// doi.org/10.4062/biomolther.2017.133 (2018).

20. Stansley, B., Post, J. \& Hensley, K. A comparative review of cell culture systems for the study of microglial biology in Alzheimer's disease. J. Neuroinflam. 9, 115. https://doi.org/10.1186/1742-2094-9-115 (2012).

21. Kielian, T., Mayes, P. \& Kielian, M. Characterization of microglial responses to Staphylococcus aureus: effects on cytokine, costimulatory molecule, and Toll-like receptor expression. J. Neuroimmunol. 130, 86-99. https://doi.org/10.1016/S0165-5728(02)00216-3 (2002).

22. Doll, J. R., Thompson, R. L. \& Sawtell, N. M. Infectious herpes simplex virus in the brain stem is correlated with reactivation in the trigeminal ganglia. J. Virol. 93, e02209-02218 (2019).

23. Brouwer, M. C., Ascione, T. \& Pagliano, P. Neurologic aspects of covid-19: a concise review. Infez. Med. 28, 42-45 (2020).

24. Walkden, H. et al. Burkholderia pseudomallei invades the olfactory nerve and bulb after epithelial injury in mice and causes the formation of multinucleated giant glial cells in vitro. PLoS Negl. Trop. Dis. 14, e0008017. https://doi.org/10.1371/journal.pntd. 0008017 (2020).

25. Frank, D. N. et al. The human nasal microbiota and Staphylococcus aureus carriage. PLoS ONE 5, e10598-e10598. https://doi.org/ 10.1371/journal.pone.0010598 (2010).

26. Jensen, A. G., Espersen, F., Skinhoj, P., Rosdahl, V. T. \& Frimodt-Moller, N. Staphylococcus aureus meningitis. A review of 104 nationwide, consecutive cases. Arch. Intern. Med. 153, 1902-1908. https://doi.org/10.1001/archinte.153.16.1902 (1993).

27. Pedersen, M., Benfield, T. L., Skinhoej, P. \& Jensen, A. G. Haematogenous Staphylococcus aureus meningitis. A 10-year nationwide study of 96 consecutive cases. BMC Infect. Dis. 6, 49. https://doi.org/10.1186/1471-2334-6-49 (2006).

28. Mathisen, G. E. \& Johnson, J. P. Brain abscess. Clin. Infect. Dis. 25, 763-779. https://doi.org/10.1086/515541 (1997).

29. Townsend, G. C. \& Scheld, W. M. Infections of the central nervous system. Adv. Intern. Med. 43, 403-447 (1998).

30. Sheen, T. R. et al. Penetration of the blood-brain barrier by Staphylococcus aureus: contribution of membrane-anchored lipoteichoic acid. J. Mol. Med. (Berl.) 88, 633-639. https://doi.org/10.1007/s00109-010-0630-5 (2010).

31. Macedo-Ramos, H. et al. Evidence of involvement of the mannose receptor in the internalization of Streptococcus pneumoniae by Schwann cells. BMC Microbiol. 14, 211. https://doi.org/10.1186/s12866-014-0211-9 (2014).

32. Delbaz, A. et al. Neisseria meningitidis induces pathology-associated cellular and molecular changes in trigeminal Schwann cells. Infect. Immun. https://doi.org/10.1128/IAI.00955-19 (2020).

33. Klionsky, D. J., Eskelinen, E. L. \& Deretic, V. Autophagosomes, phagosomes, autolysosomes, phagolysosomes, autophagolysosomes wait... I'm confused. Autophagy 10, 549-551. https://doi.org/10.4161/auto.28448 (2014).

34. Fu, R., Shen, Q., Xu, P., Luo, J. J. \& Tang, Y. Phagocytosis of microglia in the central nervous system diseases. Mol. Neurobiol. 49, 1422-1434. https://doi.org/10.1007/s12035-013-8620-6 (2014).

35. Kapellos, T. S. et al. A novel real time imaging platform to quantify macrophage phagocytosis. Biochem. Pharmacol. 116, 107-119. https://doi.org/10.1016/j.bcp.2016.07.011 (2016)

36. Wakida, N. M. et al. Phagocytic response of astrocytes to damaged neighboring cells. PLoS ONE 13, e0196153. https://doi.org/10. 1371/journal.pone.0196153 (2018).

37. Byun, Y. G. \& Chung, W.-S. in Astrocytes: Methods and Protocols (ed Barbara Di Benedetto) 155-168 (Springer New York, 2019).

38. Alkuwaity, K., Taylor, A., Heckels, J. E., Doran, K. S. \& Christodoulides, M. Group B Streptococcus interactions with human meningeal cells and astrocytes in vitro. PLoS ONE 7, e42660-e42660. https://doi.org/10.1371/journal.pone.0042660 (2012).

39. Esen, N., Tanga, F. Y., DeLeo, J. A. \& Kielian, T. Toll-like receptor 2 (TLR2) mediates astrocyte activation in response to the Grampositive bacterium Staphylococcus aureus. J. Neurochem. 88, 746-758. https://doi.org/10.1046/j.1471-4159.2003.02202.x (2004).

40. Feuerstein, G. Z., Liu, T. \& Barone, F. C. Cytokines, inflammation, and brain injury: role of tumor necrosis factor-alpha. Cerebrovasc. Brain Metab. Rev. 6, 341-360 (1994). 
41. Boka, G. et al. Immunocytochemical analysis of tumor necrosis factor and its receptors in Parkinson's disease. Neurosci. Lett. 172, 151-154. https://doi.org/10.1016/0304-3940(94)90684-X (1994).

42. Hegg, C. C., Au, E., Roskams, A. J. \& Lucero, M. T. PACAP is present in the olfactory system and evokes calcium transients in olfactory receptor neurons. J. Neurophysiol. 90, 2711-2719. https://doi.org/10.1152/jn.00288.2003 (2003).

43. Kanekar, S., Gandham, M. \& Lucero, M. T. PACAP protects against TNFalpha-induced cell death in olfactory epithelium and olfactory placodal cell lines. Mol. Cell Neurosci. 45, 345-354. https://doi.org/10.1016/j.mcn.2010.07.007 (2010).

44. Reglodi, D., Vaczy, A., Rubio-Beltran, E. \& MaassenVanDenBrink, A. Protective effects of PACAP in ischemia. J. Headache Pain 19, 19. https://doi.org/10.1186/s10194-018-0845-3 (2018).

45. Denes, V., Geck, P., Mester, A. \& Gabriel, R. Pituitary adenylate cyclase-activating polypeptide: 30 years in research spotlight and 600 million years in service. J. Clin. Med. https://doi.org/10.3390/jcm8091488 (2019).

46. Ottum, P. A., Arellano, G., Reyes, L. I., Iruretagoyena, M. \& Naves, R. Opposing roles of interferon-gamma on cells of the central nervous system in autoimmune neuroinflammation. Frontiers Immunol. https://doi.org/10.3389/fimmu.2015.00539 (2015).

47. Klein, M. A. et al. Impaired neuroglial activation in interleukin-6 deficient mice. Glia 19, 227-233. https://doi.org/10.1002/(sici) 1098-1136(199703)19:3\%3c227::Aid-glia5\%3e3.0.Co;2-w (1997).

48. Hirota, H., Kiyama, H., Kishimoto, T. \& Taga, T. Accelerated Nerve Regeneration in Mice by upregulated expression of interleukin (IL) 6 and IL-6 receptor after trauma. J. Exp. Med. 183, 2627-2634. https://doi.org/10.1084/jem.183.6.2627 (1996).

49. Nan, B., Getchell, M. L., Partin, J. V. \& Getchell, T. V. Leukemia inhibitory factor, interleukin-6, and their receptors are expressed transiently in the olfactory mucosa after target ablation. J. Comp. Neurol. 435, 60-77. https://doi.org/10.1002/cne.1193 (2001).

50. St John, J. A. et al. Burkholderia pseudomallei rapidly infects the brain stem and spinal cord via the trigeminal nerve after intranasal inoculation. Infect. Immun. 84, 2681-2688. https://doi.org/10.1128/IAI.00361-16 (2016).

51. Zhang, J.-M. \& An, J. Cytokines, inflammation, and pain. Int. Anesthesiol. Clin. 45, 27-37. https://doi.org/10.1097/AIA.0b013e3180 34194e (2007).

52. Florquin, S., Amraoui, Z., Abramowicz, D. \& Goldman, M. Systemic release and protective role of IL-10 in staphylococcal enterotoxin B-induced shock in mice. J. Immunol. 153, 2618 (1994).

53. Cheng, Y.-L. et al. Staphylococcus aureus induces microglial inflammation via a glycogen synthase kinase $3 \beta$-regulated pathway. Infect. Immun. 77, 4002-4008. https://doi.org/10.1128/iai.00176-09 (2009).

54. Arango Duque, G. \& Descoteaux, A. Macrophage cytokines: involvement in immunity and infectious diseases. Frontiers Immunol. https://doi.org/10.3389/fimmu.2014.00491 (2014).

55. Rollins, B. J. Chemokines. Blood 90, 909-928 (1997).

56. Berman, J. W., Guida, M. P., Warren, J., Amat, J. \& Brosnan, C. F. Localization of monocyte chemoattractant peptide-1 expression in the central nervous system in experimental autoimmune encephalomyelitis and trauma in the rat. J. Immunol. 156, 3017-3023 (1996).

57. Mastroianni, C. M. et al. Chemokine profiles in the cerebrospinal fluid (CSF) during the course of pyogenic and tuberculous meningitis. Clin. Exp. Immunol. 114, 210-214. https://doi.org/10.1046/j.1365-2249.1998.00698.x (1998).

58. Møller, A.-S.W. et al. Chemokine patterns in meningococcal disease. J. Infect. Dis. 191, 768-775. https://doi.org/10.1086/427514 (2005)

59. Arcuri, C., Mecca, C., Bianchi, R., Giambanco, I. \& Donato, R. The pathophysiological role of microglia in dynamic surveillance, phagocytosis and structural remodeling of the developing CNS. Front. Mol. Neurosci. 10, 191-191. https://doi.org/10.3389/fnmol. 2017.00191 (2017).

60. Vincent, A. J., Taylor, J. M., Choi-Lundberg, D. L., West, A. K. \& Chuah, M. I. Genetic expression profile of olfactory ensheathing cells is distinct from that of Schwann cells and astrocytes. Glia 51, 132-147. https://doi.org/10.1002/glia.20195 (2005).

61. Barnett, S. C. \& Riddell, J. S. Olfactory ensheathing cell transplantation as a strategy for spinal cord repair-what can it achieve?. Nat. Clin. Pract. Neurol. 3, 152-161. https://doi.org/10.1038/ncpneuro0447 (2007).

62. Gomez, R. M. et al. Cell therapy for spinal cord injury with olfactory ensheathing glia cells (OECs). Glia 66, 1267-1301. https:// doi.org/10.1002/glia.23282 (2018).

63. Chuah, M. I., Hale, D. M. \& West, A. K. Interaction of olfactory ensheathing cells with other cell types in vitro and after transplantation: glial scars and inflammation. Exp. Neurol. 229, 46-53. https://doi.org/10.1016/j.expneurol.2010.08.012 (2011).

64. Chen, M. et al. The serrulatane diterpenoid natural products RAD288 and RAD289 stimulate properties of olfactory ensheathing cells useful for neural repair therapies. Sci. Rep. 8, 10240. https://doi.org/10.1038/s41598-018-28551-2 (2018).

65. Tello Velasquez, J. et al. Low-dose curcumin stimulates proliferation, migration and phagocytic activity of olfactory ensheathing cells. PLoS ONE 9, e111787. https://doi.org/10.1371/journal.pone.0111787 (2014).

66. Hao, D. J. et al. Lipopolysaccharide and curcumin co-stimulation potentiates olfactory ensheathing cell phagocytosis via enhancing their activation. Neurotherapeutics 14, 502-518. https://doi.org/10.1007/s13311-016-0485-8 (2017).

67. Wright, A. A. et al. Enhancing the therapeutic potential of olfactory ensheathing cells in spinal cord repair using neurotrophins. Cell Transplant. 27, 867-878. https://doi.org/10.1177/0963689718759472 (2018).

68. Chen, M. et al. The plant natural product 2-methoxy-1,4-naphthoquinone stimulates therapeutic neural repair properties of olfactory ensheathing cells. Sci. Rep. 10, 951. https://doi.org/10.1038/s41598-020-57793-2 (2020).

69. Windus, L. C., Claxton, C., Allen, C. L., Key, B. \& St John, J. A. Motile membrane protrusions regulate cell-cell adhesion and migration of olfactory ensheathing glia. Glia 55, 1708-1719. https://doi.org/10.1002/glia.20586 (2007)

70. Schildge, S., Bohrer, C., Beck, K. \& Schachtrup, C. Isolation and culture of mouse cortical astrocytes. J. Vis. Exp. https://doi.org/ $10.3791 / 50079(2013)$.

71. Holt, L. M., Stoyanof, S. T. \& Olsen, M. L. Magnetic cell sorting for in vivo and in vitro astrocyte, neuron, and microglia analysis. Curr. Protoc. Neurosci. 88, e71. https://doi.org/10.1002/cpns.71 (2019).

72. Missiakas, D. M. \& Schneewind, O. Growth and laboratory maintenance of Staphylococcus aureus. Curr. Protoc. Microbiol. https:// doi.org/10.1002/9780471729259.mc09c01s28 (2013).

73. Cooley, I. D., Chauhan, V. S., Donneyz, M. A. \& Marriott, I. Astrocytes produce IL-19 in response to bacterial challenge and are sensitive to the immunosuppressive effects of this IL-10 family member. Glia 62, 818-828. https://doi.org/10.1002/glia.22644 (2014).

74. Rollin, G. et al. Intracellular survival of Staphylococcus aureus in endothelial cells: a matter of growth or persistence. Front Microbiol. 8, 1354-1354. https://doi.org/10.3389/fmicb.2017.01354 (2017).

\section{Acknowledgements}

This study was supported by a Perry Cross Spinal Research Foundation grant to JE and JS, a Clem Jones Foundation grant to JE and JS, a Menzies Health Institute Queensland Capacity Grant (Griffith University) to JE, AC and JS, a New Researcher Grant (Griffith University) to AC as well as a Research Training Program Scholarship awarded to IC. The funders had no role in study design, data collection and interpretation, or the decision to submit the work for publication. 


\section{Author contributions}

The project was planned by I.C., A.C., F.H. and J.E. Experiments were conducted by I.C., A.C., A.D., M.C., S.B. Figures were prepared by I.C., A.C. and J.S. All authors analysed the data. I.C. and A.C. wrote the main manuscript and all authors reviewed and edited manuscript. J.E. and J.S. funded the research and J.E. provided the overall supervision of the project.

\section{Competing interests}

The authors declare no competing interests.

\section{Additional information}

Supplementary Information The online version contains supplementary material available at https://doi.org/ 10.1038/s41598-021-90252-0.

Correspondence and requests for materials should be addressed to J.A.K.E.

Reprints and permissions information is available at www.nature.com/reprints.

Publisher's note Springer Nature remains neutral with regard to jurisdictional claims in published maps and institutional affiliations.

(c) (i) Open Access This article is licensed under a Creative Commons Attribution 4.0 International License, which permits use, sharing, adaptation, distribution and reproduction in any medium or format, as long as you give appropriate credit to the original author(s) and the source, provide a link to the Creative Commons licence, and indicate if changes were made. The images or other third party material in this article are included in the article's Creative Commons licence, unless indicated otherwise in a credit line to the material. If material is not included in the article's Creative Commons licence and your intended use is not permitted by statutory regulation or exceeds the permitted use, you will need to obtain permission directly from the copyright holder. To view a copy of this licence, visit http://creativecommons.org/licenses/by/4.0/.

(c) The Author(s) 2021 